\title{
A Study on Asbestos Slate Buildings in Rural Areas of Korea
}

\author{
Kang-Guk, Lee, Tae-Woo, Kim, Gi-Wook, Cha, and Won-Hwa, Hong \\ School of Architectural \& Civil Engineering \\ Kyungpook National University \\ Daegu City, South Korea \\ ggyi@naver.com
}

\begin{abstract}
Since the 1970s, in Korea, a number of buildings were found to be built with materials containing a lot of asbestos, but few stuides have been made on how much arsenic acid a building has and how much asbestos is contained in building materials as the materials become degraded. The study aims to examine current situations of the asbestos slate building in rural areas of Korea and management strategies of the Korean government in an effort to prevent the exposure to harmful substances of residents in rural areas and provide basic data for the management of the asbestos slate buildings.
\end{abstract}

Keywords-Asbestos Slate Buildings; Saemaeul Movement; living environment improvement; asbestors-containiing materials

\section{INTRODUCTION}

Until lately since the 1960s in Korea, the slate has been made of asbestos, and the roof renovation project for rural areas in Korea as part of the "Saemaeul (new communnity) Movement" in the 1970s has made asbestos-containing slate widely used for roofs in rural areas. From 2000, however, existing building in rural areas had to be rebuilt or remodeled, and construction workers and residents were highly likely to be exposed to asbestos while working at the site of rebuilding or remodeling. Since the 1970 s, in Korea, a number of buildings were found to be built with materials containing a lot of asbestos, but few studies have been made on how much arsenic acid a building has and how much asbestos is contained in building materials as the materials become degraded [1, 2]. Most residents in rural areas of Korea are old-aged who do not know much about the hazard of the asbestos due to lack of promotion and are not willing to rebuild or repair the buildings and lack in finance. A considerable number of the asbestos slate buildings in rural areas are left empty as people move from the countryside to cities [3]. At this point, the study aims to examine current situations of the asbestos slate building in rural areas of Korea and management strategies of the Korean government in an effort to prevent the exposure to harmful substances of residents in rural areas and provide basic data for the management of the asbestos slate buildings. In this study, we reviewed the literature about the use of asbestors-containing materials for slate buildings in rural areas of Korea and examined data relative to asbestos slate buildings in rural areas to have an understanding of the distribution of farm houses by

This work was supported by the National Research Foundation of Korea (NRF) grant funded by the Korea government (MSIP)( NRF2014R1A1A1004046) region, scale, and purpose. In addition, considering that is necessary to know basic facts about individual villages in order to examine the situations of the asbestos slate buildings in rural areas in Korea, we selected one administrative district for rural areas, myun, where there were many asbestos slate roof houses and investigated into the present situations and management strategies of the asbestos buildings in the areas on the basis of a field study by researchers and a survey on residents.

\section{THE USE OF THE ASBESTOS AND ASBESTOS SLATE BUILDINGS IN RURAL AREAS IN KOREA}

The Korean government's regulation on the use of the asbestos has resulted in decreasing import of raw materials and in sharply increasing import of products. Raw materials of the asbestos were imported and used as much as around 26,619 ton in 1998, and the figure sharply fell to around 383 ton in 2008. In particular, being imported around 5,009 ton in 1998 and 56,945 ton in 2007 , asbestos-containing products continues to increase. But the Korean government enacted the Occupational Safety and Health Act in February 2009 banning the manufacturing, importation, transfer, provision or use of all types of asbestos. About in 2012 95.5\% of them were used for building materials such as asbestos slate, floor tile and insulation, sprayed insulation, auto parts $(2.5 \%)$, fabrics $(0.5 \%)$, and other (1.5\%) (Fig. 1) [3].

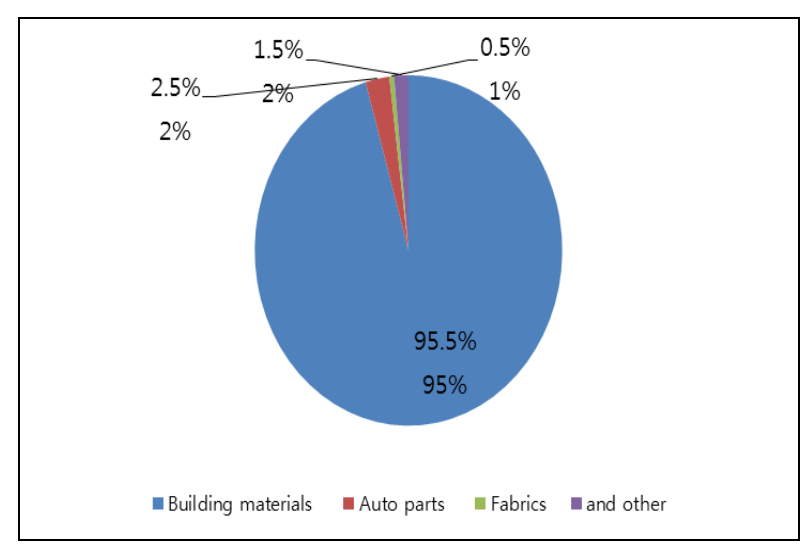

Fig. 1. Uses of the asbestos products in Korea

In 86 guns classified as a rural area in Korea, there are 2,073,744 asbestos slate buildings in Jeolanam-do (28.05\%), 
548,869 in Gyeongsang-do (26.86\%), 99,952 in Gyeonggi-do, 169,877 in Gangwon-do, 437,344 in Chungcheong-do, and 94,076 in Jeju-do in order. There are 120,424 buildings in guns within metropolitan cities classified as a large city.

Most asbestos slate buildings of rural areas were found to be located in Jeolanam-do to which the village as the region surveyed in this study belongs, in particular. Among the asbestos slate buildings in Jeolanam-do, houses account for $5,249,756 \mathrm{~m}^{2}(40.295 \%)$. In addition, $30.00 \%$ of the asbestos slate buildings in Jeolanam-do were built in the $90 \mathrm{~s}, 19.00 \%$ in the $80 \mathrm{~s}, 18.00 \%$ in the $60 \mathrm{~s}$ or earlier, and $11.00 \%$ in the $70 \mathrm{~s}$, which indicates that the asbestos slate buildings are aged 20 years or over and deteriorated, affecting a strong effect on the housing environment. Therefore, this study focused on Jeolanamdo, which is considered to be the region where most degraded slate buildings and houses are situated (Republic of Korea Ministry of Land, Transportation, \& Maritime Affairs, 2010). In this study, we chose one myeon of Jeolanamdo to do research on asbestos slate buildings in Korea's rural areas. Crops are mainly grown in this agricultural area.

\section{A. Households and population of the region}

The total area of the region for the research on asbestos slate buildings is $47.2 \mathrm{~km}^{2}$ covering 24 administrative districts, li, and the total population is 3,788 and the population density is 80 persons $/ \mathrm{km}^{2}$.

\section{B. Overview of the asbestos slate building research in the region}

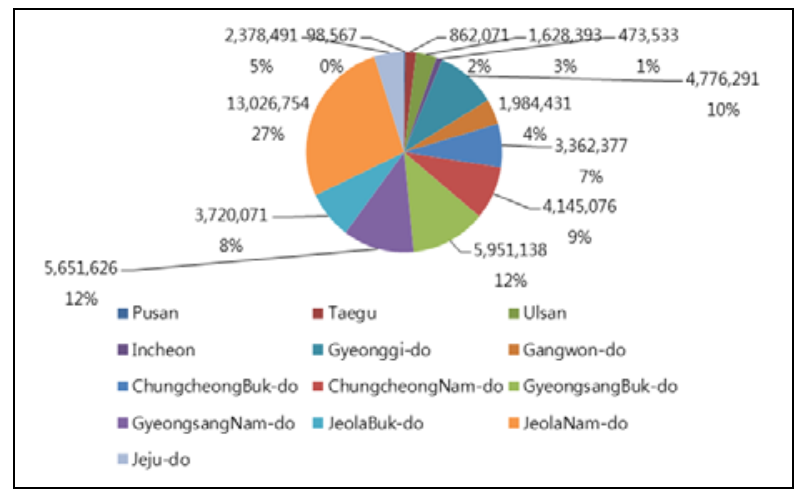

Fig. 2. Overview of the asbestos slate buildings in Korea

To carry out an investigation into asbestos slate buildings of the region, we visited households to measure building area, examine types and materials of roofs, purposes of the buildings, the number of buildings by household, and finally look into the length of eaves, slope (angle) of roofs, and expansion of eaves to calculate roof area of slate buildings.

Small flat plates, small and large corrugated types of the asbestos slate are found to be used for roofs.

\section{1) Covering of small flat plates}

Straight coverings and diamond coverings are mainly used. Roof boards $18 \mathrm{~mm}$ or over roofing or pelt are laid as a basis which is covered with main roof materials.

\section{2) Covering with corrugated slates}

a. Covering methods using with asbestos slate include direct placement onto the perling and over roof boards. In the case of corrugated rubber nails for perling, $5 \sim 6 \mathrm{~mm}$ in diameter and $75 \mathrm{~mm}$ long galvanized nails or wood nails are used, and for a steel perling, galvanized hook bolts of $6 \mathrm{~mm}$ or so in diameter are used to cover the roof.

b. Vertically overlapping asbestos slates are usually built 10 to $15 \mathrm{~cm}$, and for horizontally overlapping asbestos slates, large corrugated types are built with 0.5 grooves, small corrugated types are built with 1.5 grooves or over.

\section{Asbestos Slate Buildings in The Region}

\section{A. Overview of buildings in the region}

There are 1,314 buildings in the region; they are divided by purpose into houses $(92.85 \%)$, warehouses (4.64\%), facilities $(1.45 \%)$, pens $(0.51 \%)$, and factories $(0.91 \%)$.

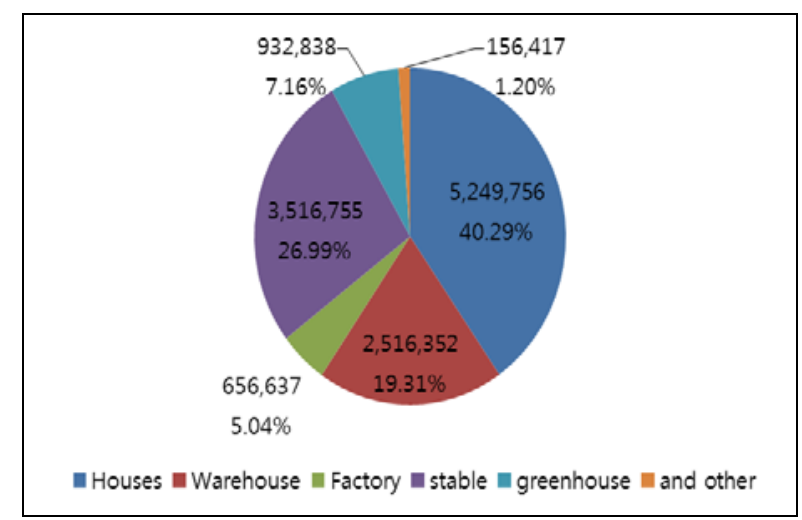

Fig. 3. Types of the asbestos slate buildings in Jeolanam-do

\section{B. Slate building area in the region}

Out of 1,314 buildings in the region, slate buildings are 659 , accounting for $50 \%$.

\section{Calculation of the area of buildings containing asbestos} slate and the amount of the asbestos slate

From the field study, we calculated the area of slate buildings using roof area against roof slope by applying random building area ( $\mathrm{H}$ and $\mathrm{W})$ as in (1):

$$
\frac{1}{\cos g}(y+a+c)(x+2 b)
$$

where,

$\theta$ : angle of the roof

$y$ : vertical length of the building

$\mathrm{a}$ : length of frontal eaves

$\mathrm{c}$ : length of rear eaves

$\mathrm{x}$ : horizontal length of the building

$2 \mathrm{~b}$ : length of side eaves 


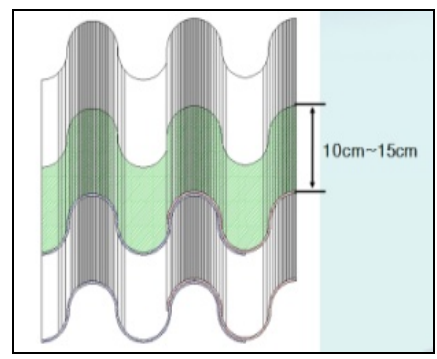

Vertical covering

Fig. 4. Vertical covering of slate roofs

The calculation of roof area by roof type with the above equation revealed that roof area of gable roofs was 1.33 larger than building area and that roof area of hipped and half-hipped roofs was 1.61 larger. In regards to the way of covering slate roofs, overlaps occurred in all directions; vertical overlap was usually built 10 to $15 \mathrm{~cm}$, and for horizontal overlap, large corrugated types were built with 0.5 grooves, small corrugated types were to be built 1.5 grooves or more, and 1.16 times more slate was found to be used. The amount of slate used for roofs in the region increased from $49 \%$ of building area up to $77 \%$. Besides, to calculate slate roof area depending on building area per household, roof type specific distribution was weighted arithmetically, and 1. 45 times more building area was applied, from the findings of the study. Given the nature of rural areas, expanded area of roof eaves accounted for $9 \%$ of the total number of slate buildings. Expansion area was $19.75 \mathrm{~m}^{2}$. As a result, the total roof area of slate buildings is the sum of (2) and (3) as below:

$$
\text { A } \times 1.45 \times 1.16
$$

where,

A : Building area

$1.45:$ Multiple of building area

1.16 : covering of the asbestos slates

$$
\mathrm{N} \times 0.09 \times 19.75
$$

where,

$\mathrm{N}$ : Total of slate buildings

0.09 : Ratio of slate buildings of which eaves were enlarged. 19.75 : Area of enlarged eaves

\section{How To Deal With and Manage Asbestos Slate OF RURAL AREAS IN KOREA}

In order to investigate into how to deal with asbestos slate of rural areas in Korea, we examined residents of the asbestos slate buildings, reasons for the introduction of the asbestos slate buildings, intention of reconstruction and renovation of the asbestos slate buildings, reason for the use of building asbestos slate, and ways to deal with waste slate after reconstruction and renovation. The survey in this study covered owners of all of the 659 houses.

\section{A. Residents of the asbestos slate buildings}

We examined ages of residents of the asbestos slate buildings (family head), dividing four age groups: 40s or younger, $50 \mathrm{~s}, 60 \mathrm{~s}$, and $70 \mathrm{~s}$ or older. As a result, it was found that those aged 70 or over accounted for $54 \%$, followed by those in their $60 \mathrm{~s}$ at $24 \%$ and those in their $50 \mathrm{~s}$ at $18 \%$ in order, indicating that aging developed considerably in rural areas of Korea.

\section{B. Reason for the introduction of the asbestos slate buildings}

Among reasons for the introduction of the asbestos slate for buildings, the government's policies (the Saemaeul Movement) accounted for $48 \%$, followed by lower prices at $33 \%$, personal tastes at $10 \%$ and recommendation by acquaintances at $9 \%$ in order. In particular, the government's policies as a reason were found to be closely related to economic aspects in connection with Korea's house renovation program when asbestos slate buildings began to be widely introduced. In addition, the reason of personal tastes is considered due to a lower level of awareness about the harmful impacts of the asbestos slate at the time of its introduction.

\section{Intention of reconstruction and renovation of the asbestos slate buildings}

Recently, most of the owners of the asbestos slate buildings in the region were found to know about the harmful effects of the asbestos slate. Accordingly, we surveyed their intention of reconstruction and renovation of the asbestos slate buildings. Although most of them wanted to reconstruct or renovate their houses, they did not do so because of a financial burden at $51 \%$, followed by $31 \%$ of them who answered that there was no problem so far and $12 \%$ of them who said that there was no reason for reconstruction and renovation. This indicates that the biggest problem for the reconstruction and renovation of the asbestos slate houses was high costs, the responses that there was a problem so far and there was no reason for reconstruction and renovation revealed that they were not fully aware of the harmful effects of the asbestos slate on housing environment in daily lives.

\section{How to deal with waste slate after reconstruction and renovation}

In regards to waste slate after reconstruction and renovation, more than $57 \%$ of it was found to be dealt with by the building owner, while $32 \%$ of the reconstruction and renovation work was found to be done by a contractor.

\section{CONCLUSION}

This study aims to provide basic data to understand the overview of the asbestos slate buildings in the rural area of Korea and management strategies for the buildings set by the Korean government prevent residents of the rural areas from being exposed to the hazards of the asbestos and protect their health.

\section{Conclusions of the study are as below:}

Firstly, out of 1,314 buildings in the region of study, 659 were slate buildings, accounting for $50 \%$. 
Secondly, from the field study of the region, we found that the total amount of the asbestos slate was $85,689.33 \mathrm{~m}^{2}$, perhouse average of slate was $60.11 \mathrm{~m}^{2}$, and per-household average of slate was $113.02 \mathrm{~m}^{2}$.

Thirdly, the survey on the residents of asbestos-containing houses in rural areas in Korea revealed that there was not sufficient awareness about the hazards of asbestos.

\section{References}

[1] J.K. Choi, D.M. Pack, N.W. Paik, S.H. Maeng, G.S. Choi, and J.K. Kang, et al. Use of and exposure to asbestos in Korea. Reports for 10th anniversary of Industrial Health Laboratory. Seoul: Graduate School of Health, Seoul National University; 1995 (in Korean).

[2] Je Yu II et al., "Asbestos and non-asbestos fiber content in lungs of Korean subjects with no known occupational asbestos exposure history," Environment International, vol. 24, Issue 3, pp. 293-300, April 1998,

[3] NSO (Korean National Statistical Office). Quarterly bulletin of international statistics, Seoul, 9: 98-107; 2014a- (in Korean). 